\title{
BMJ Open Health outcomes associated with Zika virus infection in humans: a systematic review of systematic reviews
}

Raphael Ximenes (D) , ${ }^{1}$ Lauren C Ramsay, ${ }^{1,2}$ Rafael Neves Miranda, ${ }^{1}$ Shaun K Morris, ${ }^{3,4}$ Kellie Murphy, ${ }^{5}$ Beate Sander, ${ }^{1,2,6,7}$ RADAM-LAC Research Team

To cite: Ximenes R, Ramsay LC, Miranda RN, et al. Health outcomes associated with Zika virus infection in humans: a systematic review of systematic reviews. BMJ Open 2019;9:e032275. doi:10.1136/ bmjopen-2019-032275

- Prepublication history and additional material for this paper are available online. To view these files, please visit the journal online (http://dx.doi. org/10.1136/bmjopen-2019032275).

Received 12 June 2019 Revised 25 September 2019 Accepted 27 September 2019

\section{Check for updates}

(C) Author(s) (or their employer(s)) 2019. Re-use permitted under CC BY. Published by BMJ.

For numbered affiliations see end of article.

Correspondence to Dr Raphael Ximenes; raphael.ximenes@theta. utoronto.ca

\section{ABSTRACT}

Objective With the emergence of Zika virus (ZIKV) disease in Central and South America in the mid-2010s and recognition of the teratogenic effects of congenital exposure to ZIKV, there has been a substantial increase in new research published on ZIKV. Our objective is to synthesise the literature on health outcomes associated with ZIKV infection in humans.

Methods We conducted a systematic review (SR) of SRs following Preferred Reporting Items for Systematic Reviews and Meta-Analyses guidelines. We searched MEDLINE, Embase, Cochrane and LILACS (Literatura Latino-Americana e do Caribe em Ciências da Saúde) databases from inception to 22 July 2019, and included SRs that reported ZIKV-associated health outcomes. Three independent reviewers selected eligible studies, extracted data and assessed the quality of included SRs using the AMSTAR 2 (A MeaSurement Tool to Assess Systematic Reviews 2) tool. Conflicts were resolved by consensus or consultation with a third reviewer.

Results The search yielded 1382 unique articles, of which 21 SRs met our inclusion criteria. The 21 SRs ranged from descriptive to quantitative data synthesis, including four meta-analyses. The most commonly reported ZIKV-associated manifestations and health outcomes were microcephaly, congenital abnormalities, brain abnormalities, neonatal death and GuillainBarré syndrome. The included reviews were highly heterogeneous. The overall quality of the SRs was critically low with all studies having more than one critical weakness.

Conclusion The evolving nature of the literature on ZIKVassociated health outcomes, together with the critically low quality of existing SRs, demonstrates the need for high-quality SRs to guide patient care and inform policy decision making.

PROSPERO registration number CRD42018091087.

\section{INTRODUCTION}

Zika virus (ZIKV) was first discovered in 1947 in rhesus monkeys in Uganda. ${ }^{1}$ It is an arbovirus in the flavivirus family and typically causes mild illness in humans characterised by fever and rash. There were reports of sporadic cases of ZIKV infection in humans over the years in Asia and Africa, ${ }^{2}$ with the first large documented outbreak taking place

\section{Strengths and limitations of this study}

L Lack of systematic reviews (SRs) on Zika virus (ZIKV) in the literature.

- Lack of information about the risks of severe outcomes related to ZIKV infection or the presence of specific outcomes.

- Broad search strategy.

- Without restrictions by language or publication type.

- To our knowledge, this is the first SR of SRs about health outcomes associated with ZIKV infection in humans.

in Yap, a Micronesian Island, in 2007. ${ }^{3}$ Since then, there have been reported outbreaks in French Polynesia (in 2013-2014), and most recently in South and Central America and the Caribbean. ${ }^{4}$ With the emergence of ZIKV in Brazil, there were over 800000 estimated cases of ZIKV infection reported by countries and territories in the Americas by January 2018. ${ }^{5}$ By March 2017, according to the latest WHO global situation report on Zika, 84 countries, territories or subnational areas had evidence of vector-borne ZIKV transmission. ${ }^{6}$ According to the Centers for Disease Control and Prevention (CDC), until May 2019, there were 89 areas with current or past transmission, but no current outbreak of ZIKV. ${ }^{7}$

Our understanding of Zika-associated clinical outcomes has evolved over time. Before human pathogenesis was understood, cellular level damage was apparent in animal studies in the $1950 \mathrm{~s}^{8}$ The first study in humans to suggest an association between ZIKV and human disease was a case-control study during an outbreak in French Polynesia between 2013 and 2014, suggesting an association with Guillain-Barré syndrome (GBS). ${ }^{9}$ However, the link between ZIKV in pregnant women and microcephaly in infants was only evident in the 2015-2016 outbreak in South America. ${ }^{10}$ With the spread of ZIKV to new regions of the world and the extent of the 
outbreak in South and Central American and Caribbean countries, a substantial body of new research has been published in recent years about Zika.

A bibliometric analysis of ZIKV research that indexed in Web of Science found a significant increase in the number of studies being published beginning in 2015 ( $\mathrm{n}=38$ publications) to 2017 ( $\mathrm{n}=1962$ publications) ${ }^{11}$ Summarising the large body of literature on outcomes associated with ZIKV infection is timely and needed.

The purpose of this systematic review (SR) of SRs was to synthesise the currently known health outcomes associated with ZIKV infection in humans.

\section{METHODS}

\section{Search strategy and selection criteria}

We searched MEDLINE, Embase, Cochrane and LILACS databases from inception to 22 July 2019. Our search strategy across all databases included concepts related to 'Zika' and 'systematic review' (complete search strategy found in online supplementary file 1). Our search strategy was not restricted by language or publication type. Three reviewers (RX, first reviewer; LR and RM second reviewers) independently screened titles, abstracts and relevant full text of identified articles.

The inclusion criteria were defined as SRs that reported health outcomes of ZIKV infection in humans, that is, clinical presentation and sequelae of ZIKV infection in humans. We excluded studies that only reported symptoms (eg, rash and fever) of ZIKV infection, diagnostic techniques, mosquito control, therapeutic regimes, vaccine and trial but not outcomes (eg, GBS, congenital Zika syndrome). We followed the Preferred Reporting Items for Systematic Reviews and Meta-Analyses guidelines for reporting results. ${ }^{12}$

The data extraction was performed in duplicate by the reviewers. The SR methods were established prior to the conduct of the SR and there were no deviations from the protocol, except for adding the LILACS database to the search.

\section{Patient and public involvement}

No patient involved.

\section{Quality appraisal}

We used the AMSTAR 2 (A MeaSurement Tool to Assess Systematic Reviews 2) tool to critically appraise the included SRs. ${ }^{13}$ AMSTAR 2 is not intended to generate an overall score, but rather to assist in the identification of high-quality SRs. Three reviewers (RX, first reviewer; LCR and RNM, second reviewers) independently evaluated the quality of each study based on weaknesses in critical domains as defined by the AMSTAR 2 tool. Studies were rated based on the overall confidence in the results of the SR and defined as either high (zero or one non-critical weakness), moderate (more than one non-critical weakness), low (one critical flaw with or without non-critical weaknesses) or critically low (more than one critical flaw with or without non-critical weaknesses). ${ }^{14}$ Critical domains included protocol registration, adequacy of the literature search, justification for excluding studies, risk of bias from individual studies included in the SR, appropriateness of meta-analytical methods, consideration of risk of bias when interpreting results and assessment of publication bias. ${ }^{14}$ Any disagreements between the two reviewers were resolved by consensus.

\section{Data analysis}

Three reviewers (RX, first reviewer; LCR and RNM, second reviewers) extracted the data using a structured electronic data extraction form, extracting study characteristics and measures of effect for outcomes resulting from ZIKV infection. Included studies were summarised narratively and health outcomes were reported where possible.

\section{RESULTS}

We identified 1382 unique articles from the database searches (figure 1). After screening titles and abstracts, we selected 85 for full-text screening. Of these, 21 met our inclusion criteria. ${ }^{15-35}$ The main reasons for exclusion at the full-text stage were articles not being SRs (but rather overviews or literature reviews) and studies only reported symptoms but not outcomes.

Study characteristics are summarised in table 1 . The included SRs were published between February 2016 and May 2019. The types of studies eligible for inclusion in the SRs varied across studies; four SR did not include any information on the included studies, ${ }^{21} 242830$ all other SRs included observational studies (one limited to only cohort studies $\left.^{18}\right)$ and the majority $(71 \%$; $n=15)$ included case reports and case series. Three SRs considered evidence from modelling studies, animal experiments and in vitro experiments. ${ }^{1533} 35$ Another did not limit to reports of primary data and included SRs, narrative reviews and news articles. ${ }^{20}$

The majority of studies included in the SRs were conducted in Brazil, the USA, French Polynesia and Colombia.

\section{Summary of included SRs and outcomes}

Of the 21 included SRs, the most commonly reported outcome was microcephaly, reported in 14 SRs, ${ }^{15-26} 3032$ 12 SRs reported on GBS, ${ }^{15} 16192022232527$ 29-31 3311 SRs reported on malformations or congenital abnormalities, ${ }^{18-20} 22$ 26 30-34 9 reported on brain, ${ }^{15} 1721$ 24-26 2830327 SRs reported on ocular disorders ${ }^{15182124253032}$ and 6 SRs on termination of pregnancy, fetal death and perinatal death. ${ }^{15}$ 18-20 3033 Three SRs or fewer reported on auditory disorder, ${ }^{152634}$ cardiovascular damage ${ }^{182635}$ neurological complications, ${ }^{162533}$ intrauterine growth restrictions, ${ }^{1525}$ abnormal amniotic fluid, ${ }^{15}$ epilepsy ${ }^{21}$ and death due Zika infection. ${ }^{16}$

Seven SRs focused on pregnant women ${ }^{17-20} 242628$ and five SRs included the general population, ${ }^{15} 16222329$ while 


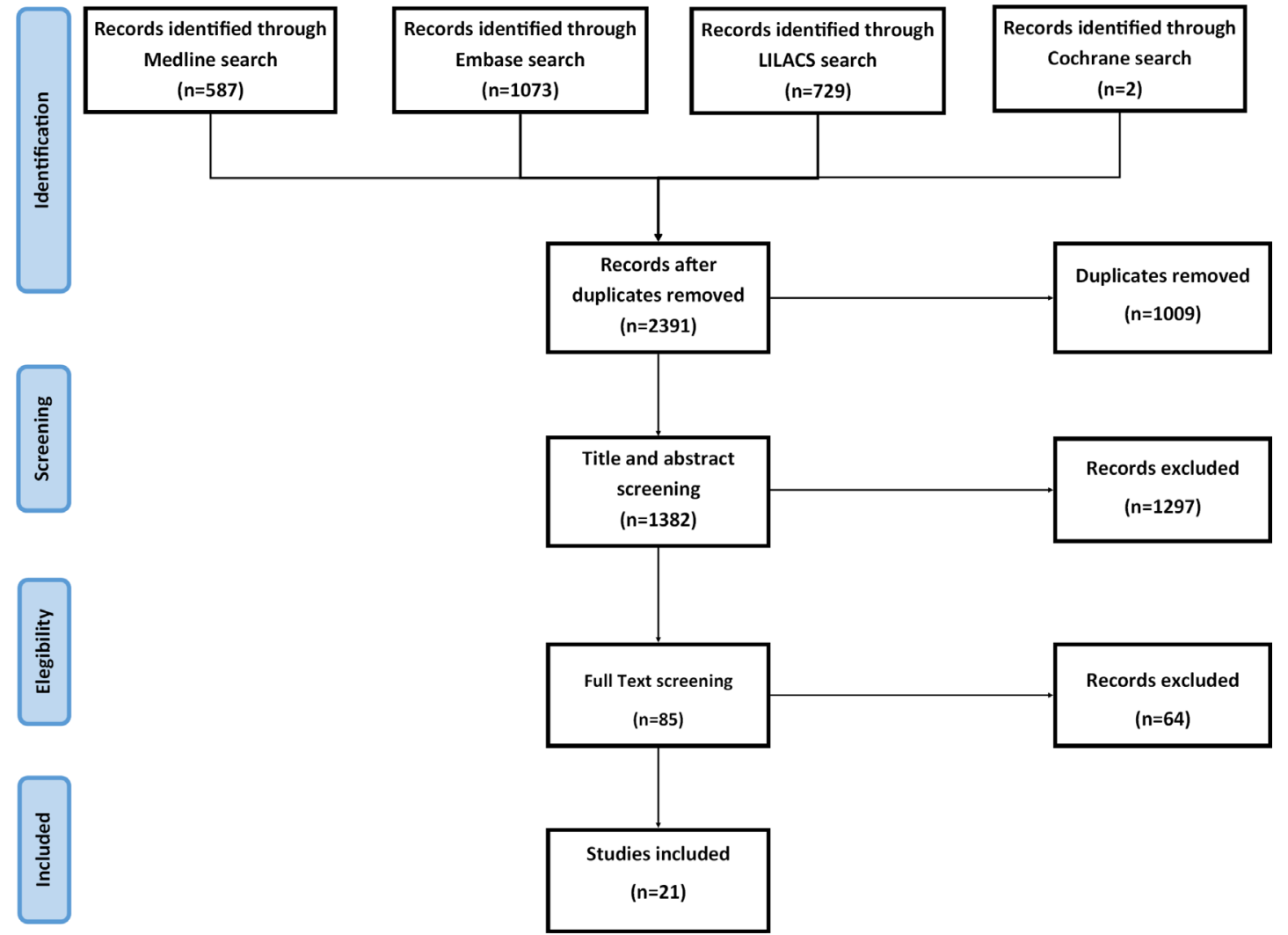

Figure 1 Preferred Reporting Items for Systematic Reviews and Meta-Analyses flow diagram of search results and study selection.

newborns, neonates, perinatal, early birth or infants were included in five SRs. ${ }^{18} 19212526$ One SR focused in travellers returning to the USA and Europe. ${ }^{31}$ Adults were included in 2 of the 15 SRs. ${ }^{25} 27$

\section{Overlap between systematic reviews}

Our SR includes 21 SRs. The overlap between the results of the 21 SRs included 860 studies (table 1), 615 of which were not duplicates. Out of the 615 studies, 477 $(77.56 \%)$ were cited only once as studies included in the SRs included in our SR, and the remainder were cited in up to 10 SRs, $83(13.50 \%)$ were cited twice, $29(4.72 \%)$ three times, $8(1.30 \%)$ four times, $8(1.30 \%)$ five times, 6 $(0.98 \%)$ six times, $2(0.33 \%)$ seven times, $1(0.16 \%)$ eight times and $1(0.16 \%)$ ten times ${ }^{36-52}$ (table 2, figure 2 ).

\section{Health outcomes}

The online supplementary file 2 reports the health outcome data extracted from the 21 SRs.

Clinical outcomes associated with ZIKV infection during pregnancy The online supplementary file 2 shows that the reported outcomes associated with ZIKV infection during pregnancy ranging from adverse birth outcomes to perinatal death. The frequency of infant deaths (miscarriages, perinatal deaths, intrauterine death or stillbirth and termination of pregnancy) was reported by 6 of 21 SRs, ${ }^{15} 18-203033$ ranging from $4.8 \%$ to $22 \%$.

Congenital Zika syndrome (CZS) was reported in many different ways. Some studies reported specific outcomes related to CZS (eg, brain abnormalities, ocular disorder or microcephaly) while others reported CZS as a nonspecific outcome. The prevalence of CZS ranged from $2 \%$ (5 cases in $250 \mathrm{ZIKV-infected} \mathrm{pregnant} \mathrm{women})^{18}$ to $50 \%$ (58 adverse congenital outcomes out of 117 women with PCR confirmed ZIKV). ${ }^{22}$

Brain abnormalities were explicitly reported with data from 19 studies in which 96\% (205 in 213 pregnant women) of fetuses were diagnosed after confirmation with imaging tests. ${ }^{15}$ One SR reported the prevalence of brain abnormalities (28\%) including microcephaly in newborns whose mothers were infected with ZIKV in pregnancy ${ }^{25}$ while other SR reported an observational study of 35 infants with microcephaly, 11 fetuses had intrauterine brain injury accompanied by stunting of cerebral growth prior to birth. ${ }^{17}$ Further, five SRs classified the type of brain abnormalities or where the lesions were found $^{21} 24283032$ as intracranial calcification, reduction in the constitution of gyri of the severe cerebral cortex, abnormal hypodensity of the white matter, malformations of cortical development, subcortical-cortical junction calcifications, basal ganglia calcification, brain calcification, intraventicular synechiae and periventricular cystic, brain volume loss, ventriculomegaly/hydrocephaly and diffuse involvement of all the cerebral lobes.

Microcephaly was reported in 14 of 21 SRs. Chibueze et $a l^{17}$ provided a trimester-specific modelling estimate risk for microcephaly. When the infection occurs in an indeterminate period of pregnancy, ZIKV-associated microcephaly 
Table 1 Summary of included SRs

\begin{tabular}{|c|c|c|c|c|c|}
\hline Author (year) & Aim & Search period & $\begin{array}{l}\text { Number } \\
\text { of studies } \\
\text { included }\end{array}$ & $\begin{array}{l}\text { Types of studies included in } \\
\text { review }\end{array}$ & $\begin{array}{l}\text { Jurisdictions of included studies ( } \mathrm{n} \\
\text { studies) }\end{array}$ \\
\hline $\begin{array}{l}\text { Krauer et al } \\
(2017)^{15}\end{array}$ & $\begin{array}{l}\text { To assess the relationship between } \\
\text { ZIKV infection and congenital brain } \\
\text { abnormalities and Guillain-Barré } \\
\text { syndrome }\end{array}$ & $\begin{array}{l}\text { From inception } \\
\text { until } 30 \text { May } \\
2016\end{array}$ & 106 & $\begin{array}{l}\text { Case reports, case series, } \\
\text { case-control studies, cohort } \\
\text { studies, cross-sectional studies, } \\
\text { ecological study/outbreak } \\
\text { reports, modelling studies, } \\
\text { animal experiments, in vitro } \\
\text { experiments, sequence analysis } \\
\text { and phylogenetics }\end{array}$ & 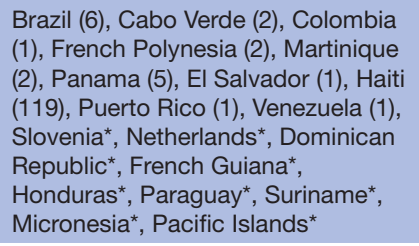 \\
\hline $\begin{array}{l}\text { Paixão et al } \\
(2016)^{16}\end{array}$ & $\begin{array}{l}\text { To summarise current knowledge on } \\
\text { ZIKV including epidemiology, clinical } \\
\text { presentation and complications }\end{array}$ & $\begin{array}{l}1954 \text { to January } \\
2016\end{array}$ & 41 & $\begin{array}{l}\text { Case reports, case series, } \\
\text { surveillance reports, } \\
\text { cross-sectional studies, } \\
\text { epidemiological bulletins and } \\
\text { alerts }\end{array}$ & $\begin{array}{l}\text { Not clearly reported } \\
\text { Most data are from Brazil and French } \\
\text { Polynesia }\end{array}$ \\
\hline $\begin{array}{l}\text { Chibueze et al } \\
(2017)^{17}\end{array}$ & $\begin{array}{l}\text { To summarise guidance on pregnancy } \\
\text { care in the context of ZIKV infection }\end{array}$ & $\begin{array}{l}\text { From inception } \\
\text { until } 3 \text { March } \\
2016\end{array}$ & 18 & $\begin{array}{l}\text { Case reports, case series, } \\
\text { observational studies }\end{array}$ & $\begin{array}{l}\text { Brazil (11) } \\
\text { Colombia (1) } \\
\text { France (1) } \\
\text { Puerto Rico (1) } \\
\text { Slovenia (1) } \\
\text { USA (2) } \\
\text { Venezuela (1) }\end{array}$ \\
\hline $\begin{array}{l}\text { Coelho et al } \\
(2017)^{18}\end{array}$ & $\begin{array}{l}\text { To summarise evidence and meta- } \\
\text { analyse data to estimate prevalence } \\
\text { of microcephaly in babies born to } \\
\text { ZIKV-infected pregnant women }\end{array}$ & Not reported & 8 & Cohort studies & $\begin{array}{l}\text { Brazil (1) } \\
\text { Colombia (1) } \\
\text { French Guiana (1) } \\
\text { Puerto Rico (1) } \\
\text { USA (4) }\end{array}$ \\
\hline $\begin{array}{l}\text { Simões et al } \\
(2016)^{19}\end{array}$ & $\begin{array}{l}\text { To assess the effects of ZIKV infection } \\
\text { on during pregnancy and postpartum } \\
\text { periods }\end{array}$ & $\begin{array}{l}\text { From inception } \\
\text { until } 23 \text { February } \\
2016\end{array}$ & 30 & $\begin{array}{l}\text { Case reports, case series, } \\
\text { guidelines }\end{array}$ & $\begin{array}{l}\text { Not clearly reported; most data are } \\
\text { from Brazil }\end{array}$ \\
\hline $\begin{array}{l}\text { Padilla et al } \\
(2016)^{20}\end{array}$ & $\begin{array}{l}\text { To review clinical and basic science } \\
\text { literature about ZIKV infection relevant } \\
\text { for obstetric anesthesiologists }\end{array}$ & $\begin{array}{l}\text { From inception } \\
\text { until } 15 \text { April } \\
2016\end{array}$ & 30 & $\begin{array}{l}\text { SRs, narrative reviews, case } \\
\text { reports, epidemiological studies, } \\
\text { government reports and news } \\
\text { articles }\end{array}$ & Not clearly reported \\
\hline $\begin{array}{l}\text { Haby et al } \\
(2018)^{23}\end{array}$ & $\begin{array}{l}\text { To estimate and meta-analyse the } \\
\text { prevalence of asymptomatic ZIKV } \\
\text { infection in the general population } \\
\text { and in specific population groups } \\
\text { from observational epidemiological } \\
\text { studies }\end{array}$ & $\begin{array}{l}\text { From inception } \\
\text { until } 26 \text { January } \\
2018\end{array}$ & 23 & $\begin{array}{l}\text { Cross-sectional seroprevalence } \\
\text { studies, case series, case- } \\
\text { control, cohort }\end{array}$ & $\begin{array}{l}\text { USA (6), Brazil (3), French Polynesia } \\
\text { (3), French Guiana (3), Puerto } \\
\text { Rico (2), Colombia (2), Spain (2), } \\
\text { Micronesia (1), Martinique (1) }\end{array}$ \\
\hline $\begin{array}{l}\text { Sarwar et al } \\
(2018)^{24}\end{array}$ & $\begin{array}{l}\text { To report on the current literature } \\
\text { regarding ZIKV and its hazardous } \\
\text { effects on maternofetal health with a } \\
\text { special emphasis on risk assessment, } \\
\text { virus transmission, associated } \\
\text { complications and possible } \\
\text { management }\end{array}$ & $\begin{array}{l}2007 \text { to May } \\
2017\end{array}$ & 69 & Not informed & $\begin{array}{l}\text { Argentina, Bolivia, Brazil, Colombia, } \\
\text { French Guiana, Suriname, Paraguay, } \\
\text { Trinidad and Tobago, Canada, } \\
\text { Dominican Republic, Grenada, } \\
\text { Guadeloupe, Guatemala, Haiti, } \\
\text { Martinique, Puerto Rico, USA, } \\
\text { Costa Rica, El Salvador, Honduras, } \\
\text { Nicaragua, Panama, Europe, } \\
\text { Slovenia, Spain, Thailand, Vietnam, } \\
\text { French Polynesia, Marshall Islands, } \\
\text { Cape Verde. }\end{array}$ \\
\hline $\begin{array}{l}\text { Wahid et al } \\
(2018)^{25}\end{array}$ & $\begin{array}{l}\text { To summarise the evidence of } \\
\text { neurological complications in ZIKV- } \\
\text { infected people }\end{array}$ & $\begin{array}{l}2015 \text { to March } \\
2017\end{array}$ & 35 & $\begin{array}{l}\text { Case-studies, case-cohort } \\
\text { studies, cross-sectional studies, } \\
\text { organisational survey reports and } \\
\text { case-control studies }\end{array}$ & $\begin{array}{l}\text { Brazil (15) } \\
\text { French Polynesia (3) } \\
\text { Colombia (3) } \\
\text { USA, Slovenia, Suriname, Spain, } \\
\text { Haiti, Martinique, Netherlands, } \\
\text { Ecuador, Guyana (1) }\end{array}$ \\
\hline
\end{tabular}


Table 1 Continued

\begin{tabular}{|c|c|c|c|c|c|}
\hline Author (year) & Aim & Search period & $\begin{array}{l}\text { Number } \\
\text { of studies } \\
\text { included }\end{array}$ & $\begin{array}{l}\text { Types of studies included in } \\
\text { review }\end{array}$ & $\begin{array}{l}\text { Jurisdictions of included studies (n } \\
\text { studies) }\end{array}$ \\
\hline $\begin{array}{l}\text { Soriano- } \\
\text { Arandes et al } \\
(2018)^{26}\end{array}$ & $\begin{array}{l}\text { To summarise the new evidence in } \\
\text { aspects of epidemiology, virology, } \\
\text { pathogenesis, associated risk } \\
\text { factors during pregnancy, newborn } \\
\text { phenotypic signs, neuroimaging, } \\
\text { laboratory diagnosis, treatment and } \\
\text { vaccines }\end{array}$ & $\begin{array}{l}\text { From inception } \\
\text { until } 30 \\
\text { November } 2017\end{array}$ & 106 & $\begin{array}{l}\text { Case series, cohort (prospective/ } \\
\text { retrospective), cross-sectional or } \\
\text { case-control studies }\end{array}$ & $\begin{array}{l}\text { Brazil, French Polynesia, USA, } \\
\text { Martinique, Colombia }\end{array}$ \\
\hline $\begin{array}{l}\text { Barbi et al } \\
(2018)^{27}\end{array}$ & $\begin{array}{l}\text { To systematically review the literature } \\
\text { and perform a meta-analysis to } \\
\text { estimate the prevalence of GBS } \\
\text { among ZIKV-infected individuals }\end{array}$ & $\begin{array}{l}\text { From inception } \\
\text { until November } \\
2017\end{array}$ & 3 & $\begin{array}{l}\text { Case series, epidemiological } \\
\text { surveys, cross-sectional or } \\
\text { cohort studies }\end{array}$ & $\begin{array}{l}\text { French Polynesia (1), Suriname } \\
\text { and Dominican Republic (1), South } \\
\text { American, Central American and } \\
\text { Caribbean countries (1) }\end{array}$ \\
\hline $\begin{array}{l}\text { Santos et al } \\
(2018)^{28}\end{array}$ & $\begin{array}{l}\text { To analyse the association between } \\
\text { Zika-virus and microcephaly during } \\
\text { the gestational period }\end{array}$ & $\begin{array}{l}\text { From inception } \\
\text { until December } \\
2016\end{array}$ & 35 & Not informed & Brazil \\
\hline $\begin{array}{l}\text { Wachira et al } \\
(2018)^{29}\end{array}$ & $\begin{array}{l}\text { To describe the factors associated } \\
\text { with development of GBS, both } \\
\text { infectious and non-infectious, through } \\
\text { an SR }\end{array}$ & $\begin{array}{l}1 \text { January } 2007 \\
\text { to } 30 \text { June } 2017\end{array}$ & 34 & $\begin{array}{l}\text { The most common were } \\
\text { case control, cohort and self- } \\
\text { controlled case series }\end{array}$ & French Polynesia \\
\hline $\begin{array}{l}\text { Pomar et al } \\
(2019)^{30}\end{array}$ & $\begin{array}{l}\text { Present a review to describe the risks } \\
\text { and complications of maternal and } \\
\text { subsequent fetal infection by ZIKV }\end{array}$ & $\begin{array}{l}\text { June } 2009 \text { to } \\
\text { November } 2018\end{array}$ & 68 & Not informed & $\begin{array}{l}\text { Colombia (3), Puerto Rico (1), French } \\
\text { Guiana (3), Brazil (1), Yap Island (1), } \\
\text { USA (2) }\end{array}$ \\
\hline $\begin{array}{l}\text { Wilder-Smith et } \\
\text { al }(2018)^{31}\end{array}$ & $\begin{array}{l}\text { Describe the burden of ZIKV infection } \\
\text { in international travellers over time; } \\
\text { estimate the proportion of birth } \\
\text { defects as a result of maternal ZIKV } \\
\text { infection in travellers; track the extent } \\
\text { of sexual transmission; summarise } \\
\text { data on ZIKV cases in travellers } \\
\text { identifying counties with reports on } \\
\text { local transmission }\end{array}$ & $\begin{array}{l}1947 \text { to April } \\
2017\end{array}$ & 65 & $\begin{array}{l}\text { Surveillance reports, case } \\
\text { reports, retrospective } \\
\text { (multicentre study), descriptive } \\
\text { retrospective analysis and } \\
\text { prospective cohort study }\end{array}$ & $\begin{array}{l}\text { USA (9), Canada (2), Germany (3), } \\
\text { Norway (1), France (5), Italy (7), Japan } \\
\text { (2), Australia (4), New Caledonia (1), } \\
\text { Finland (1), Mexico (1), Slovenia (1), } \\
\text { Netherlands (4), Belgium (1), Portugal } \\
\text { (1), Switzerland (3), Israel (1), Taiwan } \\
\text { (2), Spain (1), China (7), South Korea } \\
\text { (2), UK (2), Singapore (1), Malaysia } \\
\text { (1)USA (9), Canada (2), Germany (3), } \\
\text { Norway (1), France (5), Italy (7), Japan } \\
\text { (2), Australia (4), New Caledonia (1), } \\
\text { Finland (1), Mexico (1), Slovenia (1), } \\
\text { Netherlands (4), Belgium (1), Portugal } \\
\text { (1), Switzerland (3), Israel (1), Taiwan } \\
\text { (2), Spain (1), China (7), South Korea } \\
\text { (2), UK (2), Singapore (1), Malaysia } \\
\text { (1)USA (9), Canada (2), Germany (3), } \\
\text { Norway (1), France (5), Italy (7), Japan } \\
\text { (2), Australia (4), New Caledonia (1), } \\
\text { Finland (1), Mexico (1), Slovenia (1), } \\
\text { Netherlands (4), Belgium (1), Portugal } \\
\text { (1), Switzerland (3), Israel (1), Taiwan } \\
\text { (2), Spain (1), China (7), South Korea } \\
\text { (2), UK (2), Singapore (1), Malaysia (1) }\end{array}$ \\
\hline $\begin{array}{l}\text { Nithiyanantham } \\
\text { et al }(2019)^{32}\end{array}$ & $\begin{array}{l}\text { To conduct an SR and meta-analysis } \\
\text { on the prevalence of congenital Zika- } \\
\text { related disorders in infants of mothers } \\
\text { infected with ZIKV during pregnancy }\end{array}$ & $\begin{array}{l}\text { From inception } \\
\text { until } 31 \text { October } \\
2017\end{array}$ & 25 & $\begin{array}{l}\text { Case series, epidemiological } \\
\text { reports, prospective and } \\
\text { retrospective studies, cohort } \\
\text { studies and cross-sectional } \\
\text { studies }\end{array}$ & $\begin{array}{l}\text { USA (8), Brazil (6), Colombia (2), } \\
\text { Puerto Rico (1), French Polynesia (1), } \\
\text { Martinique (1), Trinidad and Tobago } \\
\text { (1), French Guiana (1), Ecuador (1), } \\
\text { Spain (1) }\end{array}$ \\
\hline $\begin{array}{l}\text { Masel et al } \\
(2019)^{33}\end{array}$ & $\begin{array}{l}\text { To determine if prior infection with } \\
\text { DENV, as compared with those } \\
\text { with no prior DENV infection, is } \\
\text { associated with a greater risk of ZIKV } \\
\text { complications (including neurological } \\
\text { and teratogenic outcomes), greater } \\
\text { ZIKV peak viremia, greater area- } \\
\text { under-the-curve of viremia or other } \\
\text { putative laboratory proxies of ZIKV } \\
\text { severity }\end{array}$ & $\begin{array}{l}\text { From inception } \\
\text { until } 25 \text { March } \\
2018\end{array}$ & 5 & Case-control study & Brazil (2), French Polynesia (5) \\
\hline $\begin{array}{l}\text { Barbosa et al } \\
(2019)^{34}\end{array}$ & $\begin{array}{l}\text { To describe the auditory alterations, } \\
\text { pathogenesis and recommendations } \\
\text { for follow-up in individuals with } \\
\text { prenatal or acquired ZIKV infection }\end{array}$ & $\begin{array}{l}\text { From inception } \\
\text { until April } 2019\end{array}$ & 27 & Case report and case series & $\begin{array}{l}\text { Brazil (14), Colombia (3), USA (2), } \\
\text { French Polynesia (1), Puerto Rico (1) }\end{array}$ \\
\hline $\begin{array}{l}\text { Minhas et al } \\
(2017)^{35}\end{array}$ & $\begin{array}{l}\text { Focuses on the potential threat that } \\
\text { ZIKV may pose to the heart like that } \\
\text { of similar arboviral diseases }\end{array}$ & $\begin{array}{l}\text { From inception } \\
\text { until March } 2017\end{array}$ & 3 & $\begin{array}{l}\text { Case report and prospective } \\
\text { observational multicentre study }\end{array}$ & France (1), Venezuela (1), China (1) \\
\hline
\end{tabular}


Table 2 Overlap between systematic reviews

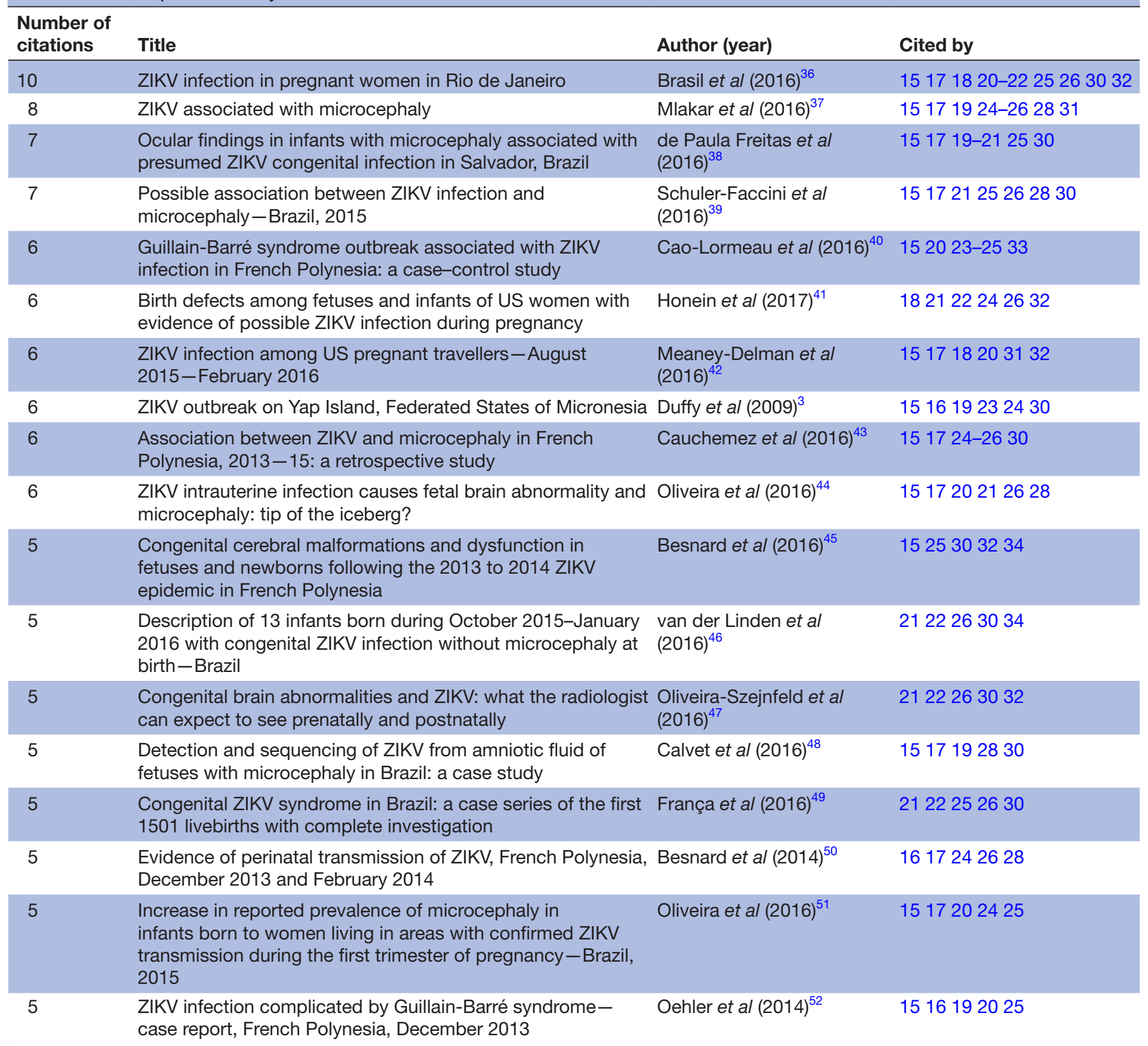

ZIKV, Zika virus.

was described by Coelho et $a l^{18}$ The authors performed a meta-analysis and found a prevalence of 2.3\% (95\% CI $1 \%$ to $5.3 \%$ ) of microcephaly when considering all pregnancies (2941 mother-infant pairs). When considering only live births (2648 live births), the prevalence of microcephaly was $2.7 \%$ (95\% CI $1.2 \%$ to $6 \%) .{ }^{18}$ Nithiyanantham $e t a l^{32}$ also performed a meta-analysis of the proportion of congenital disorders in infants born to ZIKV-infected mothers, reporting a prevalence of $3.9 \%$ (95\% CI $2.4 \%$ to $5.4 \%) .{ }^{32}$ Pomar et $a \vec{l}^{30}$ reported the prevalence of microcephaly in CZS ranging from $33.3 \%$ to $64 \% .^{30}$ Four SRs reported microcephaly cases per livebirth pregnancies, ranging from $0.2 \%$ (20 cases per 10000 live births) to $14.3 \%$ ( 1 case in seven livebirth pregnancies) $)^{15161820}$ and one SRs reported
10 microcephaly cases per 10000 births. ${ }^{19}$ Microcephaly risk in infected pregnant women was reported in four SRs. The absolute risk varied between $0.95 \%$ (95\% CI $0.34 \%$ to $1.91 \%$ ) during the first trimester of pregnancy to $30 \%^{2224-26}$ (trimester not reported). Death caused by microcephaly was estimated in a study reported by Coelho $\mathrm{et}_{\mathrm{al}} \mathrm{l}^{8}$ reporting a rate of $8.3 \%$ (171 deaths among 2063 confirmed cases of microcephaly). ${ }^{18}$ The prevalence of microcephaly in asymptomatic ZIKV infection was also reported as $0.36 \%(0.22 \%-$ $0.51 \%) .{ }^{23}$ Another SR reported that in a series of 13 infants with congenital ZIKV infection and microcephaly, more than half of the mothers did not report any symptoms of ZIKV prior to delivery. ${ }^{26}$ 


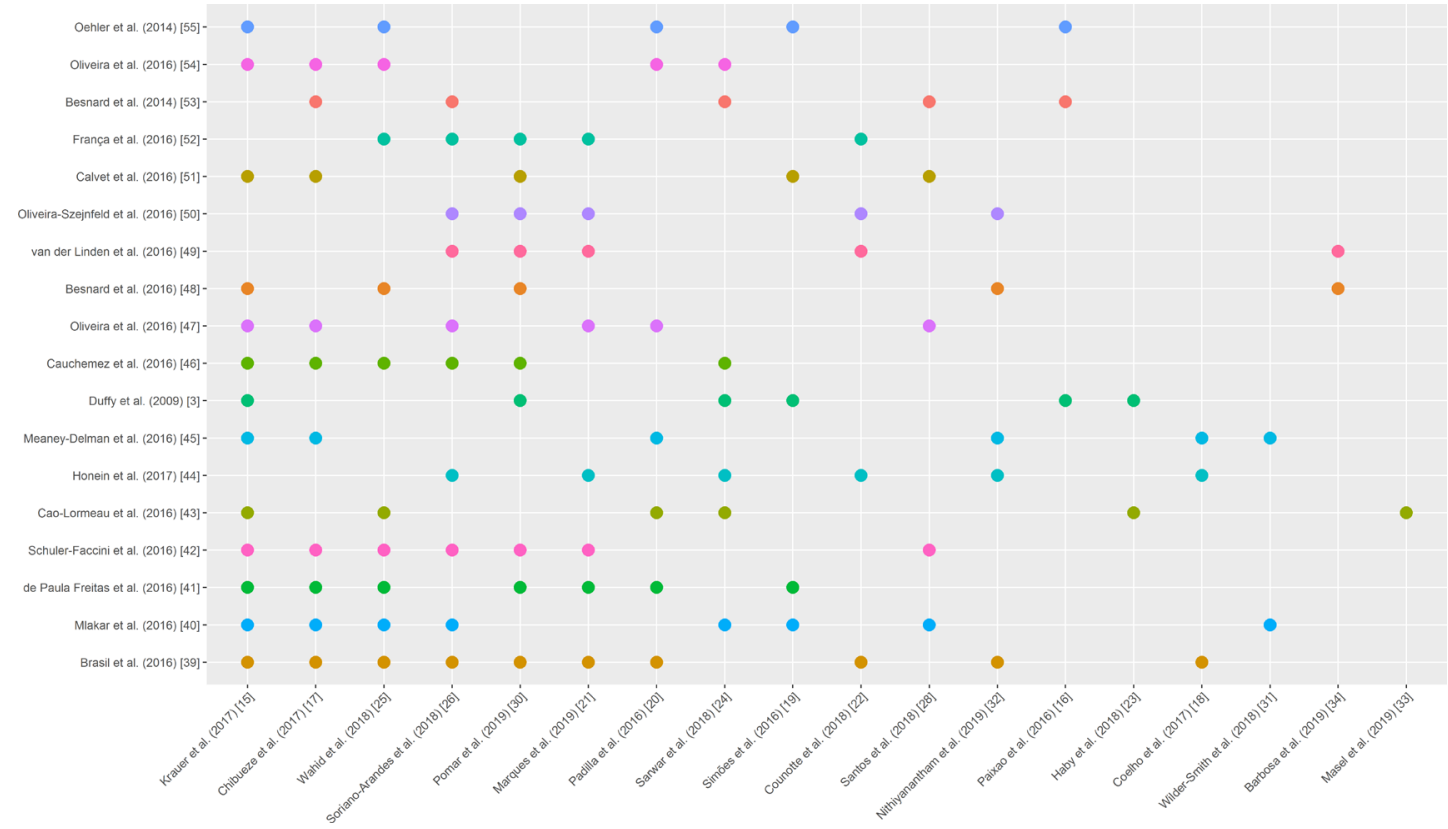

Figure 2 Overlap between studies cited in at least five systematic reviews.

The prevalence of congenital ZIKV syndrome-related outcomes is still unknown. In this SR of SRs, we found the intrauterine growth restrictions rate reported varied from $28.57 \%$ (10 cases in 35 mother-infant pairs) ${ }^{15}$ to $31.43 \%$, from one observational study of 35 infants with microcephaly. ${ }^{17}$ Another study reported intrauterine growth restriction in $11.9 \%$ of fetuses with or without microcephaly ( 5 fetuses from 42 positives for ZIKV pregnant women). ${ }^{25}$ Pomar et $a l^{30}$ reported the prevalence of intrauterine growth restriction in $14 \%$ of CZS cases. The prevalence of ocular disorder was reported in five SRs ranging from $0.9 \% \%$ (from one study with 395 livebirth pregnancies) to $58.6 \%$ (17 ocular findings with microcephaly associated in 29 infants). ${ }^{15182124253032}$ Abnormal amniotic fluid was described only by Krauer et al. ${ }^{15}$ Auditory disorder was described by Krauer $e t a l^{15}$ (prevalence of $13 \%-3$ cases in 24 mother-infant pairs) and SorianoArandes $e t a t^{26}$ (prevalence of $7 \%-5$ cases in 70 children with laboratory diagnosis of ZIKV infection) and Barbosa et $a \hat{l}^{34}$ (variations in the frequency of altered otoacoustic emissions testing (OAE) and automated auditory brainstem (a-ABR) response testing across the studies in 515 children: altered $\mathrm{OAE}$ varied from $0 \%$ to $75 \%$, while altered a-ABR varied from $0 \%$ to $29.2 \%$ ). The prevalence of cardiovascular damage was reported by Coelho $e t a l^{18}$ (prevalence of 1\% - 3 cases in 301 livebirth pregnancies), Soriano-Arandes et $a l^{26}$ (prevalence of $13.6 \%-14$ cases in103 ZIKV cases) and Minhas et $a l^{35}$ (prevalence of $67 \%$ of heart failure in a cohort with nine adults positive for ZIKV and no previous cardiac history).

\section{Neurological complications associated with ZIKV infection}

Neurological complications were reported by 12 of 21 SRs, ${ }^{16} 19-2325$ 27 29-31 33 where GBS was the most commonly reported neurological complication.
Among adults, the proportion of neurological complications associated with ZIKV infection in Bahia (Brazil) was similar to that in French Polynesia. Among these neurological complications, GBS was diagnosed in 1 of every 1000 reported Zika cases in Brazil and 1.3 per 1000 in French Polynesia. ${ }^{16}$ During the French Polynesia outbreak in 2013, the incidence of GBS has been 0.24 per $1000 \mathrm{ZIKV}$ infections, ${ }^{20}$ and Simões $e t a l^{19}$ described one case report in French Polynesia in which GBS was diagnosed in a patient with ZIKV. ${ }^{19}$

Counotte $e t a l^{22}$ reported the increased incidence of GBS incidence ratio between during and pre-ZIKV outbreak periods in seven different countries; which ranged from 2.0 (95\% CI 1.6 to 2.6 ) to 9.8 (95\% CI 7.6 to 12.5 ), while Barbi $e t a l^{27}$ conducted a meta-analysis of the prevalence of GBS in ZIKV-infected cases. Their estimate for the prevalence of GBS in adults infected with ZIKV was $1.23 \%$ (95\% CI $1.17 \%-1.29 \%)$. This same study was reported by Pomar $e t a l^{30}$. Krauer $e t a l^{15}$ reported the prevalence of symptomatic ZIKV in GBS cases (74\%-84\% symptomatic ZIKV in GBS cases). Paixão et al, ${ }^{16}$ Padilla $e t a t^{20}$ and Barbi $e t a l,{ }^{27}$ described the prevalence of admission to an intensive care unit (ranging from $36 \%$ to $42 \%$, among 42 and 38 GBS cases, respectively) and mechanical ventilation (21\% to $29 \%$ among 42 GBS cases) in French Polynesia. The interval between ZIKV and GBS symptoms was described by Krauer et al, ${ }^{15}$ Paixão $e t a l,{ }^{16}$ Padilla $e t a l^{20}$ and Counotte $e t a l{ }^{22}$ The highest interval was reported by Paixão $e t a l^{16}$ where $88 \%$ of GBS cases reported a viral syndrome up to 23 days before the onset of the neurological syndrome. No deaths due to GBS related with ZIKV infections were reported in this SR.

Epilepsy and sleep profiles were described in two SRs. For Marques et al (2019), the prevalence of epilepsy in congenital ZIKV infants ranged from $42 \%$ (43 in 


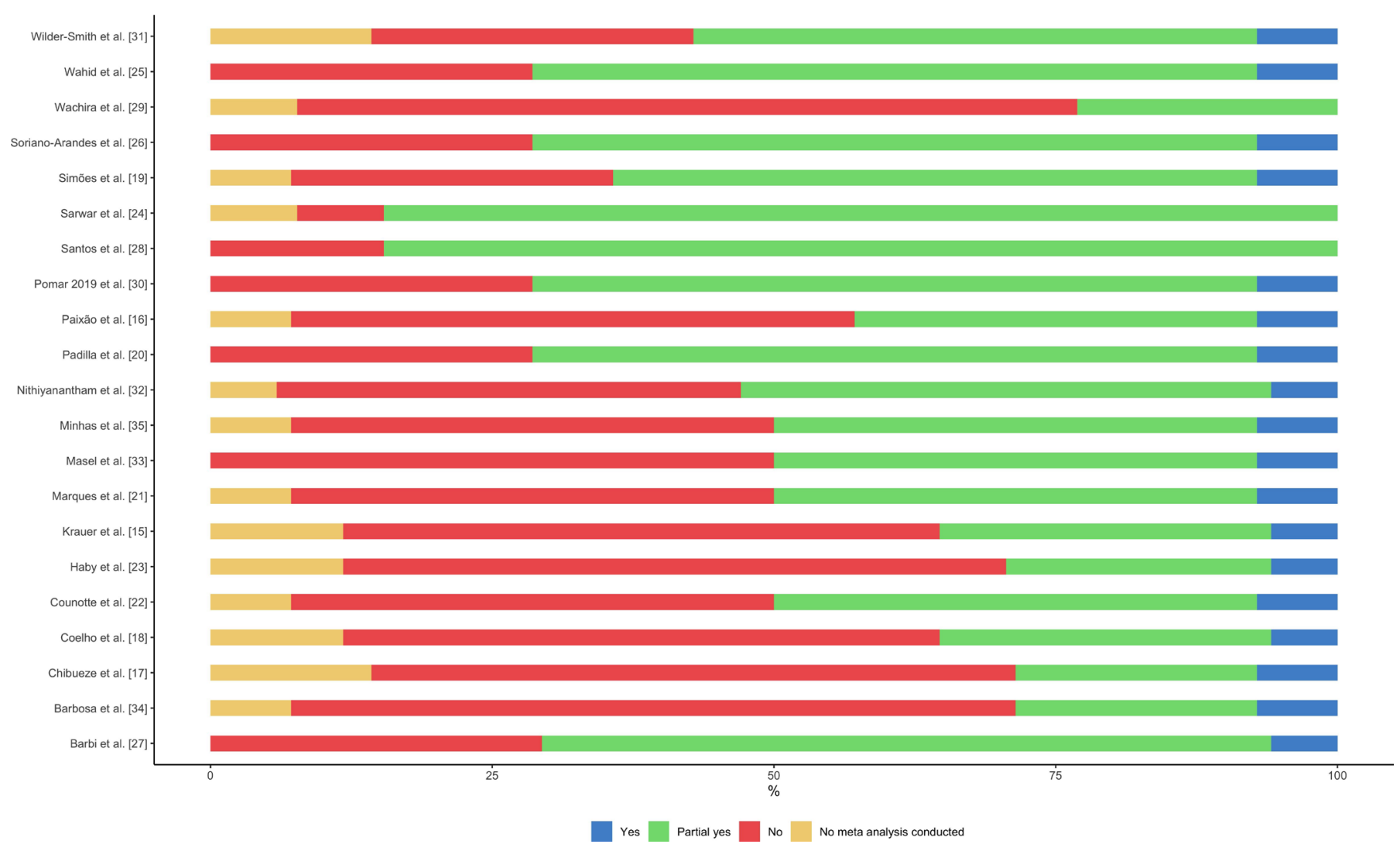

Figure 3 Individual study results of quality assessment using AMSTAR 2 (A MeaSurement Tool to Assess Systematic Reviews 2)-result for all questions of AMSTAR 2 tool.

102 children with congenital ZIKV) to $67 \%$ (95 in 141 congenital ZIKV) and 34\% (30 in 88 congenital ZIKVinfected children) of the ZIKV-infected children were defined as poor sleepers. ${ }^{21}$ Pomar $e t a l^{30}$ reported that $9 \%$ to $95.5 \%$ of congenital ZIKV infections were associated with epilepsy.

Idiopatic thrombocytopaenia purpura (ITP) related with ZIKV infection was reported by Counotte et al. ${ }^{22}$ They reported 11 cases of ITP across 18 studies; however, there is no information about the total number of ZIKVinfected subjects in these studies.

\section{Deaths associated with ZIKV infection}

Deaths due to Zika infection are rare. According to the Brazilian Ministry of Health, between 440000 and 1300000 cases of Zika occurred in Brazil in 2015. ${ }^{53} 54$ Since the beginning of the outbreak 11 deaths among adults were confirmed in Brazil and an additional nine deaths were reported by the countries and territories in the Americas. ${ }^{5}$

\section{Coinfection}

Coinfection was reported with dengue, ${ }^{16-18}{ }^{25}$ chikungunya $^{16}{ }^{1725}$ and HIV $^{16}{ }^{17}$; cytomegalovirus (CMV), toxoplasmosis or other known teratogenic agents ${ }^{16-18}$; hepatitis B virus, hepatitis $\mathrm{C}$ virus, CMV, herpes simplex virus, Epstein-Barr virus, rubella, human $\mathrm{T}$ lymphotrophic virus, parvovirus B19 and syphilis. ${ }^{17}$
Masel $e t a l^{33}$ found no association of prior exposure to Dengue Virus (DENV) and fetal loss, or clinical neurological assessment of fetus, and no statistical difference in prior DENV-exposed patients with or without GBS after ZIKV infection.

\section{Quality assessment}

Of the 21 SRs included, there was high inter-rater reliability between the reviewers $(91 \%)$. The overall quality of the SRs was critically low with all studies identified as having more than one critical weakness with or without non-critical weaknesses (figure 3). For all studies, the majority $(65 \%)$ of answers for the six critical domains of AMSTAR 2 tool (questions 2, 4, 7, 9, 12 and 14) were 'no' or 'partial yes' ( $53 \%$ and $12 \%$, respectively) (figure 4 and online supplementary file 3). Main weaknesses identified were a deficient bibliographic search strategy and the lack of an explicit statement that SR methods were established prior to the conduct of the SR.

\section{DISCUSSION}

Our SR of SRs identified 21 SRs that reported health outcomes associated with ZIKV infection. Microcephaly was the most commonly reported health outcome. Other outcomes reported were fetal death, neonatal death, congenital abnormalities including brain abnormalities, intrauterine growth restrictions, ocular disorders and 


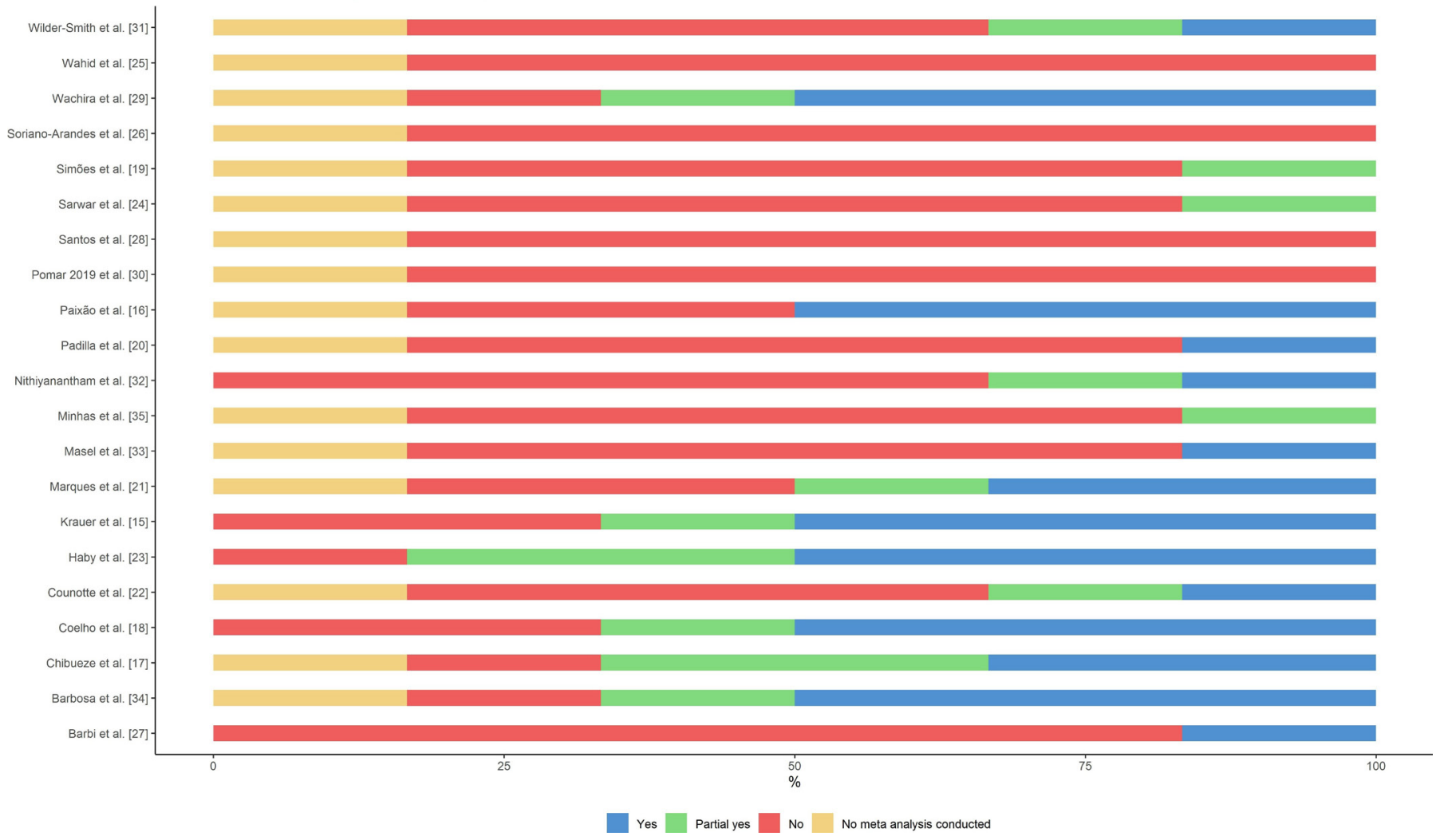

Figure 4 Individual study results of quality assessment using AMSTAR 2 (A MeaSurement Tool to Assess Systematic Reviews 2)-critical domains of AMSTAR 2 tool.

infant disorders including auditory disorders, cardiovascular damage, death due ZIKV infection, neurological complications, epilepsy and finally adult outcomes including GBS. The included SRs indicate that ZIKV infection is causally associated with congenital abnormalities, including microcephaly, and that ZIKV infection is a trigger of GBS, considering evidence on biological plausibility, the strength of association and the exclusion of alternative explanations.

Overall, we found high heterogeneity among the 21 included SRs ranging from descriptive SRs, with few data on health outcomes associated with ZIKV infection, to more quantitative SRs, including four meta-analyses. There was some overlap (22\%) of included studies across the SRs, indicating that the SRs are relatively distinct from each other and consistent with the included SRs reporting on different aspects of ZIKV infection. Given this heterogeneity, it was not possible to perform a quantitative synthesis, making it difficult to compare the results or draw conclusions based on the included SRs. Further, our quality appraisal found that all SRs were of critically low quality, with only three or fewer of six critical domains of AMSTAR 2 tool met in any study.

Further research into the magnitude of effects, potential other immediate and late outcomes, and long-term sequelae is warranted to understand the full impact of ZIKV infection, particularly long-term follow-up studies of infants born to ZIKV-infected mothers and infants and children infected with ZIKV early in life. In a recent study,
Nielsen-Saines et a $\tilde{l}^{55}$ reinforce this conclusion. They observed that the neurological phenotype in some ZIKVexposed children may change from abnormal to normal from birth into early childhood and vice versa. ${ }^{55}$

Our SR has some limitations. Since ZIKV is an emerging disease, and despite the increasing number of SRs, one limitation is the lack of SRs on ZIKV in the literature. Because the Brazilian outbreak prompted much of the recent research, 7 of 21 (33\%) included SRs were conducted fairly early in the epidemic between 2016 and 2017, 43\% in 2018 and $24 \%$ in 2019, which can explain the lack of information on severe outcomes related to ZIKV infection or the presence of specific outcomes, caused by the inability to observe outcomes that are only evident or possible to detect in older children. Often the reported data are unclear as to the nature of the infection, that is, whether included subjects are suspected ZIKV cases or confirmed ZIKV cases. Further, some of the included SRs did not report denominators, making interpretation difficult.

The low quality of the included SRs may indicate an important publication bias related to rare (eg, ITP) or poorly reported outcomes (eg, sleep disorders, epilepsy and auditory disorder) as these may not be captured in the search strategy.

Our study was strengthened by using a broad search strategy, without restrictions by language or publication type, reducing selection bias. To our knowledge, this is the first SR of SRs about health outcomes associated with ZIKV infection in humans. 
As SRs of SRs aim to provide a summary of evidence from other SRs, although we were not able to perform a meta-analysis, our SR synthesises findings from SRs on health outcomes associated with ZIKV infection in humans.

The evolving nature of the literature on ZIKV-associated health outcomes together with the critically low quality of existing SRs, confirm the need for high-quality SRs to better understand the burden of ZIKV, guide patient care and inform health policy.

\section{CONCLUSION}

Our SR demonstrates the need for future SRs on health outcomes associated with ZIKV infection as more research is published. As the ZIKV epidemic continues to evolve and the time since the emergence of the Brazilian outbreak increases we expect more primary observational studies on associated short- and long-term health outcomes to be published and synthesised in future SRs.

\section{Author affiliations}

${ }^{1}$ Toronto Health Economics and Technology Assessment (THETA) Collaborative, University Health Network, Toronto, Ontario, Canada

${ }^{2}$ Institute of Health Policy, Management and Evaluation, University of Toronto, Toronto, Ontario, Canada

${ }^{3}$ Division of Infectious Diseases and Centre for Global Child Health, Hospital for Sick Children, Toronto, Ontario, Canada

${ }^{4}$ Department of Pediatrics, Faculty of Medicine, University of Toronto, Toronto, Ontario, Canada

${ }^{5}$ Department of Obstetrics and Gynecology, Mount Sinai Hospital, Toronto, Ontario, Canada

${ }^{6}$ Public Health Ontario, Toronto, Ontario, Canada

${ }^{7}$ ICES, Toronto, Ontario, Canada

Acknowledgements The authors would like to acknowledge Andrea Tricco and Joanna Bielecki for their guidance on this project.

Collaborators RADAM-LAC Research Team members are Beate Sander, Camila Gonzalez, Manisha Kulkarni, Marcos Miretti, Mauricio Espinel, Jianhong Wu and Varsovia Cevallos.

Contributors RX: conceptualisation of the study, performed the systematic review, critically appraising the scientific literature, analysis, drafting and revising the manuscript. RNM: performed the systematic review, critically appraising the scientific literature and revising the manuscript. LCR: performed the systematic review and critically appraising the scientific literature. SKM: critical revision of the manuscript. KM: critical revision of the manuscript. RADAM-LAC Research Team: contribution to study conception and design. BS: conceptualisation of the study, critical revision of the manuscript and supervision of the study.

Funding This project was funded by the Canadian Institutes of Health ResearchTeam grant—FRN149784 and the International Development Research Centre (IDRC).

\section{Competing interests None declared.}

Patient consent for publication Not required.

Provenance and peer review Not commissioned; externally peer reviewed.

Data availability statement All data relevant to the study are included in the article or uploaded as supplementary information.

Open access This is an open access article distributed in accordance with the Creative Commons Attribution 4.0 Unported (CC BY 4.0) license, which permits others to copy, redistribute, remix, transform and build upon this work for any purpose, provided the original work is properly cited, a link to the licence is given, and indication of whether changes were made. See: https://creativecommons.org/ licenses/by/4.0/.
ORCID iD

Raphael Ximenes http://orcid.org/0000-0003-2536-951X

\section{REFERENCES}

1 World Health Organization. The history of Zika virus, 2017. Available: https://www.who.int/emergencies/zika-virus/timeline/en/ [Accessed 10 Dec 2018].

2 Posen HJ, Keystone JS, Gubbay JB, et al. Epidemiology of Zika virus, 1947-2007. BMJ Glob Health 2016;1:e000087.

3 Duffy MR, Chen T-H, Hancock WT, et al. Zika virus outbreak on YAP Island, Federated states of Micronesia. N Engl J Med 2009;360:2536-43.

4 Kindhauser MK, Allen T, Frank V, et al. Zika: the origin and spread of a mosquito-borne virus. Bull World Health Organ 2016;94:675-86.

5 Pan American Health Organization / World Health Organization. Zika suspected and confirmed cases reported by countries and territories in the Americas cumulative cases, 2015-2017, 2017. Available: https://www.paho.org/hq/index.php?option=com_docman\&view= download\&category_slug=cumulative-cases-pdf-8865\&alias $=43296$ zika-cumulative-cases-4-january-2018-296\&ltemid=270\&lang=en [Accessed 9 Feb 2019].

6 World Health Organization. Sltuation report zika virus microcephaly guillain-barré syndrome 10 march 2017 data as of 9 march, 2017. Available: https://apps.who.int/iris/bitstream/handle/10665/254714/ zikasitrep10Mar17-eng.pdf?sequence $=1$ [Accessed 9 Feb 2019].

7 CDC. Zika Travel Information, Travelers' Health. Available: https:// wwwnc.cdc.gov/travel/page/zika-travel-information [Accessed 28 May 2019].

8 Dick GWA. Zika virus. II. pathogenicity and physical properties. Trans $R$ Soc Trop Med Hyg 1952;46:521-34.

9 Cao-Lormeau V-M, Blake A, Mons S, et al. Guillain-Barré syndrome outbreak associated with Zika virus infection in French Polynesia: a case-control study. Lancet 2016;387:1531-9.

10 de Araújo TVB, Rodrigues LC, de Alencar Ximenes RA, et al. Association between Zika virus infection and microcephaly in Brazil, January to may, 2016: preliminary report of a case-control study. Lancet Infect Dis 2016;16:1356-63.

11 Saima Nasir JA. A bibliometric analysis of research on Zika virus indexed in web of science. Adv Life Sci 2018;5:88-95.

12 Moher D, Shamseer L, Clarke M, et al. Preferred reporting items for systematic review and meta-analysis protocols (PRISMA-P) 2015 statement, 2015. Available: http://www.crd.york.ac.uk/prospero

13 AMSTAR. Assessing the Methodological Quality of Systematic Reviews [Internet]. Available: https://amstar.ca/Amstar-2.php [Accessed 4 Dec 2018].

14 Shea BJ, Reeves BC, Wells G, et al. AMSTAR 2: a critical appraisal tool for systematic reviews that include randomised or nonrandomised studies of healthcare interventions, or both. BMJ 2017.

15 Krauer F, Riesen M, Reveiz L, et al. Zika virus infection as a cause of congenital brain abnormalities and Guillain-Barré syndrome: systematic review. PLoS Med 2017;14:e1002203.

16 Paixão ES, Barreto F, Teixeira MdaG, et al. History, epidemiology, and clinical manifestations of Zika: a systematic review. Am J Public Health 2016;106:606-12.

17 Chibueze EC, Tirado V, Lopes KdaS, et al. Zika virus infection in pregnancy: a systematic review of disease course and complications. Reprod Health 2017;14:28.

18 Coelho A, Crovella S, Coelho AVC. Microcephaly prevalence in infants born to Zika virus-infected women: a systematic review and meta-analysis. Int J Mol Sci 2017;18:1714.

19 Simões R, Buzzini R, Bernardo W, et al. Zika virus infection and pregnancy. Rev Assoc Med Bras 2016;62:108-15.

20 Padilla C, Pan A, Geller A, et al. Zika virus: review and obstetric anesthetic clinical considerations. J Clin Anesth 2016;35:136-44.

21 Marques VdeM, Santos CS, Santiago IG, et al. Neurological complications of congenital Zika virus infection. Pediatr Neurol 2019;91:3-10.

22 Counotte MJ, Egli-Gany D, Riesen M, et al. Zika virus infection as a cause of congenital brain abnormalities and Guillain-Barré syndrome: from systematic review to living systematic review. PLoS Med 2018;7.

23 Haby MM, Pinart M, Elias V, et al. Prevalence of asymptomatic Zika virus infection: a systematic review. Bull World Health Organ 2018;96:402-13.

24 Rehan Sarwar M, Saqib A, Iftikhar S. Zika virus infection during pregnancy; Maternofetal risk assessment, transmission, complications, and management: a review of the literature. Arch Clin Infect Dis 2018;13. 
25 Wahid B, Ali A, Waqar M, et al. An updated systematic review of Zika virus-linked complications. Asian Pac J Trop Med 2018;11:1.

26 Soriano-Arandes A, Rivero-Calle I, Nastouli E, et al. What we know and what we don't know about perinatal Zika virus infection: a systematic review. Expert Rev Anti Infect Ther 2018;16:243-54.

27 Barbi L, Coelho AVC, Alencar LCAde, et al. Prevalence of GuillainBarré syndrome among Zika virus infected cases: a systematic review and meta-analysis. Braz $J$ Infect Dis 2018;22:137-41.

28 Santos GRBD, Aragão FBA, Lobão WJdeM, et al. Relationship between microcephaly and Zika virus during pregnancy: a review. Rev Assoc Med Bras 2018;64:635-42.

29 Wachira VK, Peixoto HM, Fernandes De Oliveira MR. Systematic review of factors associated with the development of Guillain-Barr E syndrome 2007-2017: what has changed? 2018. Available: https:// v2dis-prod.evidencepartners.com/Generic/getAttachment2.php?id= 44

30 Pomar L, Musso D, Malinger G, et al. Zika virus during pregnancy: from maternal exposure to congenital Zika virus syndrome. Prenat Diagn 2019;39:420-30.

31 Wilder-Smith A, Chang CR, Leong WY. Zika in travellers 1947-2017: a systematic review. J Travel Med 2018;25.

32 Nithiyanantham SF, Badawi A. Maternal infection with Zika virus and prevalence of congenital disorders in infants: systematic review and meta-analysis. Can J Public Health 2019.

33 Masel J, McCracken MK, Gleeson T, et al. Does prior dengue virus exposure worsen clinical outcomes of Zika virus infection? A systematic review, pooled analysis and lessons learned. PLoS Negl Trop Dis 2019;13:e0007060.

34 Barbosa MH de M, de M-BMC, Robaina JR, et al. Auditory findings associated with Zika virus infection: an integrative review. Braz $J$ Otorhinolaryngol 2019

35 Minhas AM, Nayab A, lyer S, et al. Association of Zika virus with myocarditis, heart failure, and arrhythmias: a literature review. Cureus 2017;9:e1399.

36 Brasil P, Pereira JP, Moreira ME, et al. Zika virus infection in pregnant women in Rio de Janeiro. N Engl $J$ Med 2016;375:2321-34.

37 Mlakar J, Korva M, Tul N, et al. Zika virus associated with microcephaly. N Engl J Med 2016;374:951-8.

38 de Paula Freitas B, de Oliveira Dias JR, Prazeres J, et al. Ocular findings in infants with microcephaly associated with presumed Zika virus congenital infection in Salvador, Brazil. JAMA Ophthalmol 2016;134:529.

39 Schuler-Faccini L, Ribeiro EM, Feitosa IML, et al. Possible Association Between Zika Virus Infection and Microcephaly - Brazil, 2015. MMWR Morb Mortal Wkly Rep 2016;65:59-62.

40 Cao-Lormeau V-M, Blake A, Mons S, et al. Guillain-Barré syndrome outbreak associated with Zika virus infection in French Polynesia: a case-control study. The Lancet 2016;387:1531-9.

41 Honein MA, Dawson AL, Petersen EE, et al. Birth defects among fetuses and infants of US women with evidence of possible Zika virus infection during pregnancy. JAMA 2017;317.
42 Meaney-Delman D, Hills SL, Williams C, et al. Zika virus infection among U.S. pregnant travelers - August 2015-February 2016. MMWR Morb Mortal Wkly Rep 2014;65:211-4.

43 Cauchemez S, Besnard M, Bompard P, et al. Association between Zika virus and microcephaly in French Polynesia, 2013-15: a retrospective study. Lancet 2016;387:2125-32.

44 Oliveira Melo AS, Malinger G, Ximenes R, et al. Zika virus intrauterine infection causes fetal brain abnormality and microcephaly: tip of the iceberg? Ultrasound Obstet Gynecol 2016;47:6-7.

45 Besnard M, Eyrolle-Guignot D, Guillemette-Artur P, et al. Congenital cerebral malformations and dysfunction in fetuses and newborns following the 2013 to 2014 Zika virus epidemic in French Polynesia. Euro Surveill 2016;21.

46 van der Linden V, Pessoa A, Dobyns W, et al. Description of 13 Infants Born During October 2015-January 2016 With Congenital Zika Virus Infection Without Microcephaly at Birth - Brazil. MMWR Morb Mortal Wkly Rep 2016;65:1343-8.

47 Soares de Oliveira-Szejnfeld P, Levine D, Melo ASdeO, et al. Congenital brain abnormalities and Zika virus: what the radiologist can expect to see prenatally and postnatally. Radiology 2016;281:203-18.

48 Calvet G, Aguiar RS, Melo ASO, et al. Detection and sequencing of Zika virus from amniotic fluid of fetuses with microcephaly in Brazil: a case study. Lancet Infect Dis 2016;16:653-60.

49 França GVA, Schuler-Faccini L, Oliveira WK, et al. Congenital Zika virus syndrome in Brazil: a case series of the first 1501 livebirths with complete investigation. The Lancet 2016;388:891-7.

50 Besnard M, Lastère S, Teissier A, et al. Evidence of perinatal transmission of Zika virus, French Polynesia, December 2013 and February 2014. Euro Surveill 2014;19. doi:10.2807/1560-7917. ES2014.19.13.20751. [Epub ahead of print: 03 Apr 2014].

51 Kleber de Oliveira W, Cortez-Escalante J, De Oliveira WTGH, et al. Increase in Reported Prevalence of Microcephaly in Infants Born to Women Living in Areas with Confirmed Zika Virus Transmission During the First Trimester of Pregnancy - Brazil, 2015. MMWR Morb Mortal Wkly Rep 2016;65:242-7.

52 Oehler E, Watrin L, Larre P, et al. Zika virus infection complicated by Guillain-Barre syndrome--case report, French Polynesia, December 2013. Euro Surveill 2014;19. doi:10.2807/1560-7917. ES2014.19.9.20720. [Epub ahead of print: 06 Mar 2014].

53 Anthony Boadle LP. Exclusive: Brazil says Zika virus outbreak worse than believed | Reuters [Internet]. Reuters, 2016. Available: https://www.reuters.com/article/us-health-zika-brazil-exclusiveidUSKCNOVA331 [Accessed cited 2018 Dec 4].

54 World Health Organization. Zika situation report - zika and potentia complications, 2016. Available: https://www.who.int/emergencies/ zika-virus/situation-report/who-zika-situation-report-12-02-2016.pdf [Accessed 4 Dec 2018].

55 Nielsen-Saines K, Brasil P, Kerin T, et al. Delayed childhood neurodevelopment and neurosensory alterations in the second year of life in a prospective cohort of ZIKV-exposed children. Nat Med 2019;25:1213-7. 